\title{
Neurocranial Morphology of the Albanian Kosovo Population
}

\author{
Morfología Neurocranial de la Población Albanesa de Kosovo
}

\author{
Agron M. Rexhepi",*,** \& Behlul Brestovci****
}

REXHEPI, A. M. \& BRESTOVCI, B. Neurocranial morphology of the Albanian Kosovo population. Int. J. Morphol., 32(1):97-100, 2014.

SUMMARY: The purpose of this research publication in reference to the morphological features of the head of a Kosovo Albanian population takes us one step further toward studying the anthropological status of Kosovo Albanian population. Three cephalofacial variables were measured in 754 Kosovo subjects, between 18-35 years of age, 561 male and 193 female. The categorization of the head size of the treated subjects was done based on the head length (G-Op), head width (Eu-Eu), and head height (V-Po), according to the Lebzelter-Saler scale (head length and width) and Routil scale (head height). Results show that the head of the male subjects was characterized by long (50.1\%), large (49.7\%) and medium high head (46\%), whereas, female subjects was characterized by a medium long $(50.3 \%)$, medium large $(50.8 \%)$ and low head type (41\%). In general, the morphologic results of the head, match the results of the other authors, who found similarities between the morphologic features of the Dinaric type (Iliric) and Albanian population.

KEY WORDS: Head length; Head width; Head height; Dinaric; Iliric.

\section{INTRODUCTION}

The measurements of cephalofacial variables are of high importance for anthropologists because they enable the chronological study of the nations' anthropology (Dhima, 1985; Ylli, 1975).

Among sophisticated methods for evaluation of the craniofacial form (photogrametry, ultrasound, computed tomographic, scanning magnetic imaging, optical surface scanning) cephalometry, because of its practicality, continues to be the most applicable technique in measuring of the craniofacial skeleton. This method, as a branch of anthropometry, is widely used as diagnostic, treatment, and research tool by many physicians and anthropologists (Rexhepi \& Meka, 2008).

Cephalometry or measurement of human head is an anthropometric method used in identification, forensic medicine, clinical diagnosis, plastic surgery, oral and maxillofacial surgery, orthodontics, archeology and ethnoanthropology.
Many anthropologists are interested in the morphological type of the Albanians because they descend directly from the Ilirs, and were spread along a vast territory in the ancient Europe.

The Albanian territories and population belong to Dinaric type of the humans, which is a fundamental morphological type of the European population.

The Dinaric type of humans is known as Ilir type, represents a tall stature, thin and muscular type, strong ossifications, wide shoulders, wide chest, the equal and well developed extremities medium sized, with a wide and long cranium, long face, and horizontal cephalic index indicates that the head belongs to brachiocephalic type (Coon, 1950; Drontc'ilov, 1921; Dhima; Glück, 1897; Pittard, 1916; Rexhepi \& Meka; Ylli; McCulloch, 2013).

The aim of this study was to establish the morphological characteristics of the head of Kosovo

\footnotetext{
* Sport Center for increasing of morpho-functional abilities, Fitness \& Nutrition "Corpore Sano", Prishtina, Kosovo.

** College for Sport Education - Universi, Pristina, Kosovo.

*** Faculty of Special Education and Rehabilitation, University of Zagreb, Zagreb, Croatia.
} 
Albanian population (both sexes) and the categorization of the head with regard to length, width and height dimensions of the head.

\section{MATERIAL AND METHOD}

This study as a part of the project: "Morphological characteristics of Kosovo Albanian population" has been realized by the Institute of Sports Anthropology in Prishtina, Kosovo.

The measurements of the head were carried out in 754 subjects of the Kosovo Albanian population (561 male and 193 female), 18-35 years of age. The entities were chosen randomly, respecting the rule that their psychophysic, dental and soft tissue condition were normal. So, all subjects with abnormality of the face and scalp soft tissues, deviation of the spinal cord, shoulder and uneven extremities, have been eliminated from further study and measurements.

Following the definitions of Martin \& Saler (1957) the measurements were taken by an anthropological cephalometer GMP, with measurement interval of $300 \mathrm{~mm}$ and accuracy of $1 \mathrm{~mm}$, and a sliding rule modified for cephalometric and gnathometric measurements. According to the International Biological Programme (IBP) (Buzina et al., 1975) the following variables were measured:

G-Op - Maximum head length (glabelaopistocranion, G-Op) was measured by spreading caliper. The anterior caliper tip was resting on glabella, whereas the posterior tip slid inferiorly along medial line of occipital until maximum length was reached;

Eu-Eu - Maximum head width (Eurion-eurion, eu- eu) was measured by spreading caliper, sliding both tips of caliper down lateral sides of parietal bones, forward and back until maximum width was reached;

V-Po - Head height (Vertex-porion, v-po) was measured on the right and left sides of the head using a double sliding caliper and a level.

The obtained data were analyzed in terms of basic statistical parameters. While the categorization of the treated subjects by their head features were done based on the distribution of their values according to respective scale. The categorization of the gained results for head height and head width were done based on the Lebzelter-Saler scale, whereas head height according to the Routil scale.

\section{RESULTS}

The findings of the basic statistic parameters (Mean, Min. and Max. values, and SD) for the measured variables in treated subjects (males and females) are shown in Tables I and II.

The low values of Standard Deviation, calculated for each measured variable, indicate that measured variables have normal and concentrated dispersion near their mean values (Tables I and II)

In Table III are presented the categorization and distribution of the values for the measured variables of the treated subjects (male and female). This Table (III) shows the results of the head length and width based on the Lebzelter-Saler scale and the head height according to the Routil scale.

Table I. Descriptive statistics of male subjects.

\begin{tabular}{llllll}
\hline Variables & $\mathrm{n}$ & Min. & Max. & Mean & SD \\
\hline G-Op & 561 & 168.00 & 209.00 & 188.79 & 6.31 \\
Eu-Eu & 561 & 116.00 & 191.00 & 157.71 & 6.46 \\
V-Po & 561 & 104.00 & 143.00 & 121.52 & 6.97 \\
\hline
\end{tabular}

Table II. Descriptive statistics of female subjects.

\begin{tabular}{llllll}
\hline Variables & $\mathrm{n}$ & Min. & Max. & Mean & SD \\
\hline G-Op & 193 & 164.00 & 200.00 & 180.14 & 6.53 \\
Eu-Eu & 193 & 138.00 & 168.00 & 152.61 & 5.72 \\
V-Po & 193 & 96.00 & 134.00 & 114.67 & 6.92 \\
\hline
\end{tabular}


Table III. Classification of the measured subjects based on the head dimensions.

\begin{tabular}{|c|c|c|c|c|c|c|}
\hline \multirow{2}{*}{$\begin{array}{l}\text { Head Length G-Op } \\
\text { (Lebzelter-Saler scale) } \\
\text { Very short head }\end{array}$} & \multicolumn{3}{|c|}{ Males } & \multicolumn{3}{|c|}{ Females } \\
\hline & $x-169$ & 1 & $0.20 \%$ & $x-161$ & 0 & $0 \%$ \\
\hline Short head & $170-177$ & 19 & $3.40 \%$ & $162-169$ & 7 & $3.6 \%$ \\
\hline Medium long head & $178-185$ & 146 & $26 \%$ & $170-177$ & 54 & $28 \%$ \\
\hline Long head & $186-193$ & 281 & $50.10 \%$ & $178-185$ & 98 & $50.8 \%$ \\
\hline Very long head & $194<$ & 114 & $20.30 \%$ & 186-x & 34 & $17.6 \%$ \\
\hline $\begin{array}{l}\text { Head Width Eu-Eu } \\
\text { (Lebzelter-Saler scale) }\end{array}$ & \multicolumn{3}{|c|}{ Males } & \multicolumn{3}{|c|}{ Females } \\
\hline Very narrow head & $>139$ & 5 & $0.90 \%$ & $\mathrm{x}-133$ & 0 & $0 \%$ \\
\hline Narrow head & $140-147$ & 14 & $2.50 \%$ & $134-141$ & 3 & $1.6 \%$ \\
\hline Medium large head & $148-155$ & 178 & $31.70 \%$ & $142-149$ & 47 & $24.3 \%$ \\
\hline Large head & $156-163$ & 279 & $49.70 \%$ & $150-157$ & 100 & $51.8 \%$ \\
\hline Very large head & $164<$ & 85 & $15.20 \%$ & $158-\mathrm{x}$ & 43 & $22.3 \%$ \\
\hline $\begin{array}{l}\text { Head Height V-Po } \\
\text { (Routil scale) }\end{array}$ & \multicolumn{3}{|c|}{ Males } & \multicolumn{3}{|c|}{ Females } \\
\hline Very low head & $\mathrm{x}-109$ & 29 & $5.20 \%$ & $\mathrm{x}-103$ & 6 & $3.1 \%$ \\
\hline Low head & $110-117$ & 129 & $23 \%$ & $104-111$ & 58 & $30.1 \%$ \\
\hline Medium high head & $118-125$ & 258 & $46.00 \%$ & $112-119$ & 80 & $41.5 \%$ \\
\hline High head & $126-133$ & 115 & $20.50 \%$ & $120-127$ & 41 & $21.2 \%$ \\
\hline Very high head & $134<$ & 30 & $5.30 \%$ & $128-\mathrm{x}$ & 8 & $4.1 \%$ \\
\hline
\end{tabular}

\section{DISCUSSION}

The categorization of the head with regard to the length of the head (Tables I and III) shows that the majority of the male subset $(50.1 \%)$ belonged to the category with long head, the other subjects are spread among the categories of medium long head (26\%) and very long head (20.3). The female subset was characterized mainly $(50.8 \%)$ with long head, $28 \%$ with medium long head and $17.6 \%$ with very long head (Tables II and III).

The categorization of the head with regard to the head width (Table III) shows that the $49.7 \%$ of the studied subjects belonged to the group with large head, $31,7 \%$ with medium large head and $15.2 \%$ to the group with very large head. As for female subjects, $51.8 \%$ of them belonged to the group with large head, $24.3 \%$ with medium large head and 22.3\% with very large head (Table III).

The categorization of the head with regard to the head height (Table III) shows that the $46 \%$ of the male subset belonged to the group with medium high head, $23 \%$ with low head and $20.5 \%$ with high head. Similar with male population, the $41.5 \%$ of the treated female population belonged to the group with medium high head, $30.1 \%$ with low head, and $21.2 \%$ with high head.

\section{CONCLUSION}

Male and female subjects have similar morphology of the head, characterized with a long, large and medium high head. The morphologic types of the current population cannot easily be separated, because among the different types, interfere types with intermediate features (Dhima; Ylli; McCulloch). But, in general the morphologic results of the head from this research, concur with the results of other authors, who found similarities between the morphologic features of the Dinarik type (Iliric) and Albanian population (Coon; Drontc'ilov; Dhima; Gavrilovic 1981; Glück; Pittard; Ylli; McCulloch).

REXHEPI, A. M. \& BRESTOVCI, B. Morfología Neurocranial de la Población Albanesa de Kosovo.Int. J. Morphol., 32(1):97-100, 2014.

RESUMEN: El propósito de esta investigación referente a las características morfológicas de la cabeza en la población albanesa de Kosovo, es un paso más en el estudio de su condición antropológica. Se midieron tres variables cefalofaciales en 754 sujetos de Kosovo entre 18-35 años de edad, correspondientes a 561 hombres y 193 mujeres. La categorización del tamaño de la cabeza fue realizada en base a la longitud de la cabeza (G-Op), ancho de la cabeza (Eu-Eu), y altura de la cabeza (V-Po) de acuerdo a la escala Lebzelter-Saler (longitud y ancho de la cabeza) y la escala Routil 
(altura de la cabeza). Los resultados muestran que la cabeza de los hombres se caracterizó por ser larga (50,1\%), de gran tamaño $(49,7 \%)$ y altura media (46\%), mientras que en las mujeres se caracterizó por una longitud media $(50,3 \%)$, tamaño medio $(50,8 \%)$ y altura baja (41\%). En general, los resultados morfológicos de la cabeza, concuerdan con los resultados de otros autores que encontraron similitudes entre las características morfológicas del tipo Dinárico (Ilírics) y la población albanesa.

PALABRAS CLAVE: Longitud de la cabeza; Ancho de la cabeza; Altura de la cabeza; Dináricos; Ilíricas.

\section{REFERENCES}

Buzina, R.; Grgic, Z.; Kovacevic, M.; Maver, H.; Momirovic, K.; Rudan, P.; Schmucer, Lj. \& Stampar-Plasaj, B. Praktikum bioloske antropologije - Antropometrija. Zagreb: Sekcija za biolosku antropologiju ZLH i SIZ za zaposljavanje, 1975.

Coon, C. S. The mountains of Giants. A Racial and Cultural Study of the North Albanian Mountain Ghegs. Cambridge, Peabody Museum of American Archaeology and Ethnology, 1950. p.105.

Dhima, A. Gjurmime antropologjike për shqiptaret. Tirana, Mihail Duri, 1985. pp.28-9, 106-12, 126-8.

Drontc'ilov, K. Prinos kám antropologijata na Albancite. Periodichesko spisanie na Balgarskoto Knizhovno Druzhestvo, 27:111-37,1921.

Gavrilovic, Z. \& Bozic, V. Morfoloske i biotipolos` ke karakteristike odraslih i starih osoba. Glasnik Antropolos `og Drustva Jugoslavije, 18:33-81, 1981.

Glück, L. Zur physischen anthropologie der Albanesen. Wissenschaften und Mitteilungen aus Bosnien und der Hercegovina, 5:365-402, 1897.

Martin, R. \& Saller, K. Lehrbuch der anthropologie. Stuttgart, Gustav Fischer Verlag, 1957.

McCulloch, R. The nordish race. 2013. Available in: http:// www.racialcompact.com/nordishrace.html

Pittard, E. Les peuples des Balkans. Paris, Esquisses anthropologique, 1916. pp.84-5.

Rexhepi, A. \& Meka, V. Cephalofacial morphological characteristics of Albanian Kosova population. Int. J. Morphol., 26(4):935-40, 2008.
Ylli, A. Disa të dhëna kraniometrike. Tirana, Mihail Duri, 1975. pp.64-97.

Correspondence to:

Agron M. Rexhepi

Str. "Sali Butka" Nr.31/D

10000 Prishtina

KOSOVO

Phone: +37744110855

Email: agronmrexhepi@gmail.com

Received: 16-06-2013

Accepted: 19-11-2013 